Revista Transgressões: ciências criminais em debate, v. 5, n. 2, Outubro 201\%, Natal/RN

\title{
O DESCOMPASSO ENTRE A REALIDADE MIDIÁTICA E A REALIDADE PROCESSUAL E SUAS IMPLICAÇÕES PARA O JULGAMENTO CRIMINAL JUSTO
}

\section{Luanny Galvão Almeida}

E-mail: luannygalvao@gmail.com

\section{RESUMO}

Abordar-se-á aspectos relacionados à realidade dos fatos trazidos pela mídia ao julgamento criminal, ao qual tem importante papel na sociedade, quanto à fiscalização, publicidade das informações, como também, a sua interferência para a construção de uma realidade irreal, através da espetacularização dos fatos. A partir de um método dedutivo, tem o intuito de analisar, a influência desta na construção da realidade, através de uma abordagem com uso de casos concretos, mostrando a dissonância existente entre a realidade dos fatos e a realidade midiática. A realização desta pesquisa possui um objetivo descritivo, por meio do uso de um objeto bibliográfico.

PALAVRAS-CHAVE: Mídia. Manipulação. Sistema Judiciário. 


\section{INTRODUÇÃO}

O presente trabalho tem por escopo apresentar uma sucinta discussão acerca da questão do crescente poder exercido pela mídia jornalística brasileira, que influi sobre o julgamento criminal justo. De forma que a mesma possui como principal função social: o dever de informar. Todavia, em um país como o Brasil, de população carente e de baixa escolaridade, a mídia passa a formar a opinião daquele cidadão que ao assistir um noticiário ou ler uma página de jornal é, inconscientemente, levado a concordar com aquela informação que lhe é apresentada.

Objetiva-se então, mostrar a construção da realidade a partir da mídia, que influi na opinião pública, à medida que essa última se mostra afetada pelo interesse midiático em obtenção ao lucro sem que haja o compromisso com a verdade real dos fatos. Dessa forma, é construído o imaginário do espectador, que se vê em um ambiente repleto de violência, consequentemente tomado pelo medo.

Além disso, destaca-se o conflito existente quanto ao direito constitucional à liberdade de expressão e o direito ao julgamento criminal justo, por meio de uma análise crítica, com pesquisa de dois casos práticos, mostrando assim as duas vertentes, quanto ao dever de informar, quando este é respeitado pelo jornalismo ético, e quando este é violado.

\section{MÍDIA E O SEU PÚBLICO ALVO}

O termo mídia é bastante amplo, compreende conforme Almeida e Gomes (2013, p.99), “diversos meios difusores e produtores de mensagens informativas, o jornal e a revista compõe a mídia impressa, enquanto a televisão e a internet atuam no campo da mídia visual, sendo estes os meios que constituem a "mídia massa"". Sendo simultaneamente um meio de expressão, como também um intermediário capaz de transmitir certa mensagem a um grupo. Logo, a mídia tem, como principal função disseminar informações no meio social.

Ela vai além de observar usuários de internet, pessoas que passam horas diante da televisão ou lendo jornais. É necessário entender o que a mídia faz com a sociedade, e o que a sociedade faz com ela. Afirma Silverstone (2005, p.16) que devemos "estudá-la como algo que contribui para a nossa variável capacidade de compreender o mundo, de produzir e partilhar seus significados". A mídia é uma forma de espetáculo e suas formas de narrativa, 
como as novelas, os programas de rádio, os telejornais, dentre outros são integrantes da vida social. E conforme Silverstone (2005) passamos a nos identificar com ela. Trataremos neste trabalho a atividade jornalística, especificadamente do jornalismo justiceiro, termo que será discutido adiante.

Em relação ao público, em meio ao contexto social de desigualdade vivido no Brasil, no qual o poder crítico, de conhecimento e de investigação de uma parte da população é restrito, principalmente no contexto dos programas policiais, em que há alteração da realidade ou dos fatos reais, a população é convencida a pensar como os grandes veículos jornalísticos norteiam, passando a ver a justiça, através do espectro construído por eles.

Posto isto, o principal público alvo da mídia jornalística é a classe mais desfavorecida economicamente, formando a 'grande massa', uma legião de pessoas 'manobradas' pelo o que a mídia expõe, gerando espectadores assíduos, defensores dos interesses postos pela mídia, e tendo assim, a informação dada por estes veículos de comunicação como a verdade fiel, incontestável e confiável.

Esta confiança sob a informação imposta pela mídia jornalística advém da carência educacional do país. Existem pessoas que não possuem senso crítico, que acabam recebendo o que é transmitido pela mídia, que o faz de maneira simplista, clara, para entendimento da população, que possui limitações quanto ao acesso à justiça, à notícia com credibilidade, ao linguajar jurídico utilizado pelo defensor, promotor, juízes, etc. que ao serem veiculados pelos meios de comunicação, tornam-se bem mais claros, o entendimento dos atos processuais.

O papel da mídia jornalística é trazer ao seu espectador a informação dos fatos de forma objetiva para que aquele possa compreender a verdade dos fatos, tornando-se um elemento de 'poder', o chamado quarto poder da República, ao qual iremos abordar no tópico a seguir.

\subsection{A FORÇA SIMBÓLICA DO QUARTO PODER}

Como já visto, a mídia jornalística tem como papel divulgar informações, tornaramse um bem, que além de ser uma fonte de conhecimento e riqueza, tornou-se também um instrumento de poder. Conforme nos mostra Pierre Bourdieu (2000), um poder de influência, de manipulação, de conduzir indiretamente a sociedade, as massas, de acordo com a intenção dos que o detêm e utilizam. 
Ainda de acordo com o sociólogo francês (2000, p.9), "o poder simbólico é um poder de construção da realidade que tende a estabelecer uma ordem gnoseológica: o sentido imediato do mundo (...) uma concepção homogênea (...)”. Um poder que observamos na realidade brasileira através da televisão e da mídia impressa.

A expressão "quarto poder" configurou-se a partir do início do século XX na Inglaterra, em razão da forte influência que a mídia exerce sobre as pessoas, no que diz respeito a seus gostos, vontades e opinião.

No Brasil torna-se tão simbolicamente forte que muitas vezes chega a ultrapassar os três poderes políticos, quais sejam: Executivo, Legislativo e Judiciário, exercendo assim, influência e representação na mentalidade da coletividade. E por consequência, a população acredita mais no que é veiculado nos telejornais, do que está posto nos autos do processo. Tornando-se pessoas de fácil manipulação, um alvo fácil para o poder simbólico, que se encontra por trás da mídia e de grupos dominantes. E assim nos surge o seguinte questionamento: como se dá essa manipulação por parte da mídia? Buscaremos a resposta para essa questão, nos próximos tópicos deste artigo.

\subsection{A MÍDIA NA FORMAÇÃO DA CONSCIÊNCIA}

Uma das principais características do jornalismo, praticado pela maioria da mídia, é a manipulação da informação. O principal reflexo destaé que os órgãos de imprensa não refletem a realidade, esta é distorcida, artificial, não real, é criada e transformada. Segundo Abramo (2003, p. 24):

A relação entre a imprensa e a realidade é parecida com aquela entre um espelho deformado e um objeto que ele aparentemente reflete: a imagem do espelho tem algo a ver com o objeto, mas não só não é o objeto como também é a sua imagem; é a imagem de outro objeto que não corresponde ao objeto real.

Ou seja, o público é constantemente colocado diante de uma realidade artificialmente criada, que se contradiz, sobrepõe a real, que a população vive e conhece, é a que o espectador não percebe diretamente, mas que aprende por conhecimento. Conforme exemplifica Almeida e Gomes (2013, p. 227-228): 
informação - sempre é simplificável, redutível, capaz de converter-se em espetáculo de massa e decompor-se num certo número de segmentos-emoções.

A repetição da notícia em vários canais de comunicação a torna verdadeira, se um acontecimento é veiculado na televisão e no rádio de uma emissora de grande confiança daquele espectador esta informação passa ser verdadeira, mesmo que seja falso, porque a informação foi disseminada em diversos meios de comunicação, e o ora espectador possui apenas como meio de verificação, o confronto entre os diferentes meios de comunicação. Então, logo pensa: se todos afirmam a mesma coisa, resta apenas admitir aquilo como real, verdadeiro.

É neste contexto em que há a transformação da informação, assim, em manipulação da realidade. Importante destacar, que não é toda informação que é manipulada pela imprensa, se assim o fosse, o fenômeno seria autodesmistificador por si mesmo.

Também não podemos dizer que é um fenômeno que ocorra uma vez ou outra, se fosse o caso, os efeitos seriam igualmente insignificantes. Existem diversos padrões de manipulação pela imprensa de acordo com Abramo (2003), apresentaremos alguns destes:

- Padrão de ocultação

- Padrão de fragmentação

- Padrão de inversão

- Padrão de indução

- Padrão global

O primeiro padrão se refere à ausência de fatos reais na produção da imprensa. Acontece no momento em que se edita uma matéria, em seu planejamento. Sendo uma espécie de manipulação do real, ao qual haverá a separação do que é, e não é jornalístico. $\mathrm{O}$ fato dependerá da linha editorial a ser traçada por aquele determinado veículo de comunicação. (ABRAMO, 2003)

Como assevera Abramo (2003, p. 27), “o fato real foi eliminado da realidade, ele não existe. O fato real ausente deixa de ser real para se transformar em imaginário”, passando existir, uma realidade diferente, sendo a verdade criada pela imprensa.

Após a eliminação dos fatos não-jornalísticos, adentramos ao padrão de fragmentação, ao qual o "resto" é apresentado pela imprensa, porém ainda não como se 
apresenta a realidade dos fatos. O todo real é fragmentado em diversos fatos particulares, na maior parte desconectada entre si, desligada dos seus antecedentes e da sequência em que ocorram. E assim, a imprensa seleciona o que apresentará ou não.

O terceiro padrão, chamado de inversão, usa aqueles fatos desconectados, descontextualizados, reordenando suas partes, e sua importância dentro de um contexto, criando novamente uma nova realidade (ABRAMO, 2003).

A inversão ocorre quando há a troca do geral pelo particular, do principal pelo secundário, o detalhe pelo essencial. Está presente quando se preza mais a forma do que o conteúdo, quando o texto passa a ser mais importante que o fato que ele reproduz, o ficcional espetaculoso sobrepondo à realidade (ABRAMO, 2003).

Não é o fato em si que tem importância, mas a versão que dele tem o órgão de imprensa, gerando versões opinativas, e como afirma Abramo (2003, p.29): "se o fato não corresponde à minha versão, deve haver algo errado com o fato". É preciso entender, que todos os padrões de manipulação aqui já vistos não ocorrem necessariamente em todas as matérias e programas auditivos ou televisivos. Há processos de manipulação mínimos, imperceptíveis ou frutos de erros quanto à captação de informações sobre a realidade. Deve-se levar em conta o grau de intensidade da utilização da manipulação.

O quarto poder de manipulação é o da indução, como explica Abramo (2003, p. 32):

(...) O que torna a manipulação um fato essencial e característico da maioria da grande imprensa brasileira hoje é que a hábil combinação dos casos, dos momentos, das formas e dos graus de distorção da realidade submete, em geral e em seu conjunto, a população à condição de excluída da possibilidade de ver e compreender a realidade real e a induza a consumir outra realidade, artificialmente inventada.

O espectador ou leitor é induzido a ver o mundo não como ele é, mas sim como a mídia quer que ele veja. São assuntos que são vistos todos os dias enquanto outros jamais, ou quase nunca, serão tratados pela mídia. Grupos sociais que são enfatizados em determinadas matérias enquanto outros são evitados por conveniência da grande mídia jornalística, aquela que é mais poderosa, o meio de comunicação que possui maior audiência ou tiragem, os que veiculam mais publicidade.

O último padrão de manipulação, o global, também intitulado de padrão específico do jornalismo de televisão e rádio, abarca todos os quatro padrões já vistos, mas ainda apresenta três momentos básicos, quais sejam: a exposição do fato, que é apresentado em seu ângulo mais sensacionalista, emocional; o segundo momento é o da "sociedade fala" em que apresenta os depoimentos, dores, alegrias, críticas e propostas dos personagens envolvidos; o 
terceiro, é o que a autoridade resolve, tratando um fato natural, como uma greve, assalto, homicídio etc., em que a autoridade anunciará providências, reprimindo o mal e enaltecendo o bem. A autoridade tranquiliza o povo, Abramo (2003, p.36) corrobora com esse pensamento e acrescenta que "a autoridade (...) desestimula qualquer ação autônoma e independente do povo, mantém o povo ao controle dela, autoridade”. Diante deste cenário veremos no próximo tópico, a delimitação desta mídia, o jornalismo chamado de justiceiro.

\section{JORNALISMO “JUSTICEIRO"}

Expressão utilizada por Almeida e Gomes (2013, p. 107) ao qual:

Defende de uma maneira bastante peculiar, os interesses dos vitimizados, dos desamparados, dos injustiçados, dos desprotegidos etc. (...) Se apresenta como defensor da moralidade social ou da moralidade pública, ou seja, quando atua contra os malfeitores que violam (ou se acham na iminência de violar) a legalidade, colocando em risco a estabilidade social ou institucional.

O jornalismo que aqui está sendo enfocado não é o mesmo que se limitava à narrativa dos fatos noticiados ou investigados. Hoje investiga, acusa, julga e aplica sanções morais. Age como um terceiro que toma parte no debate, expondo seu ponto de vista. Este ‘tipo' de jornalismo atua em defesa da ordem social, atacando ou desmascarando algumas pessoas que a perturbam, por meio da violação das leis.

$\mathrm{Na}$ medida em que o Estado foi perdendo sua capacidade de resolver conflitos sociais, a mídia jornalística naturalmente foi ganhando mais espaço, como afirma Almeida e Gomes (2013, p. 108) “transformou-se em 'palco' das discussões e das reivindicações, assim como um veículo das 'soluções' para graves problemas sociais". Esta acabou por se apropriar de papéis que não eram seus, levando ao apoderamento de questões criminais. Como serão discutidas a seguir, questões acerca dos aspectos negativos e positivos, quanto a este jornalismo ‘justiceiro'.

\section{ASPECTOS NEGATIVOS DA MÍDIA JORNALÍSTICA}

Não é de hoje que o Direito Penal e a Mídia andam juntos, desde os primórdios da sociedade, a humanidade é fascinada por notícias que envolvem crimes. E a imprensa não tem 
como ficar alheia a este fato. Veículos como jornais impressos, revistas, noticiário televisivo e radiofônico, dedicam um significativo espaço para esse tipo de notícia.

Acontece que a divulgação reiteradas vezes acaba por potencializar um clima de medo, insegurança na população, há uma banalização da violência, do crime. Serão estes aspectos, que trataremos nos tópicos a seguir.

\subsection{BANALIZAÇÃO DA VIOLÊNCIA E DO CRIME}

A mídia jornalística mascara a realidade através da manipulação. Isto se dá de maneira constante em programas de notícia ${ }^{33}$ através da espetacularização ${ }^{34}$. Exemplificando, no âmbito do telejornalismo local (Natal/RN), podemos citar diversos programas policialescos que diversas vezes, dramatizam a dor humana em cenas de pessoas mortas, uma perda violenta a fim de explorar a ideia de que "bandido bom é bandido morto". É um telejornal que dá um grande espaço aos acontecimentos negativos, aos voltados para a violência e a morte. Buscando sempre um culpado contra quem a sociedade possa se voltar gerando, por diversas vezes, cenas dignas de ficção. É uma verdadeira espetacularização do crime. Cabe então aqui, expandir as definições sobre o que vem a ser violência.

O dicionário Houaiss (2015) define o termo como "constrangimento físico ou moral exercido sobre alguém, para obrigá-lo a submeter-se à vontade de outrem; coação". O que as notícias veiculam com maior frequência é este constrangimento físico e moral sofrido por seus entrevistados com o intuito de vendê-los como espetáculo.

A mídia tenta transmitir a ideia de que o sistema penal está falido, e como a mesma não é investida em jurisdição, acaba por agir como “operadora” e criadora do Direito, no aspecto, de condenar ou absolver suspeitos e acusados antes mesmo da conclusão do processo penal. Trazendo a ideia de que as leis existentes são ineficientes, dando como solução a criação de leis mais severas ${ }^{35}$.

\footnotetext{
${ }^{33}$ O Povo na TV (SimTV), Balanço Geral RN (TV Tropical), Cidade Alerta (TV Tropical), Rio Grande do Norte Urgente (Band Natal) e Patrulha da Cidade (TV Ponta Negra).

${ }^{34}$ O termo faz referência à sociedade do espetáculo, detectada por Guy Debord na década de 1960, como sendo uma cultura onde tudo é vivido a partir de representações, de simulacros, sendo que só existe o que é transmitido pelos meios de comunicação de massa (DEBORD, 1997).

${ }^{35}$ Como exemplo tem-se a Lei 8.072 de 1990, que elencou os chamados crimes hediondos, e a Lei Complementar 135 de 2010, a Lei da Ficha Limpa.
} 
A mídia jornalística extrapola a atividade de informar ao explorar as misérias cotidianas, exagerando no linguajar, e consequentemente, banalizando o crime. Chegando a exercer, funções como bem ilustra Padilha Neto (2006):

O jornalista, transcendendo o seu mister, traveste-se de delegado, promotor e juiz, tudo ao mesmo tempo, apura, acusa e condena a pessoa objeto de sua investigação, em um trabalho que ele chama de jornalismo investigativo, mas que não passa de tribunal de exceção.

Corroborando com o mesmo pensamento, Njaine reforça (2003):

No caso das coberturas jornalísticas relacionadas à violência, uma coisa é certa: seja o veículo impresso ou eletrônico, em geral há uma carência de melhor qualificação dos repórteres envolvidos - um problema bastante relacionado à falta de espaço para reflexão nas Faculdades de Comunicação. Ao exercer a profissão, o jornalista reproduz a velha prática de tratar o fenômeno a partir do fato violento em si, desconsiderando as causas e o contexto. O quadro tende a ser mais problemático nas redações que mantêm a figura do repórter policial ou nas chamadas editorias de polícia. Normalmente, esses profissionais dependem muito de fontes policiais, já que consideram central para seu trabalho os furos de reportagem.

São emissoras que disponibilizam um repórter para verificar os informes da polícia, as operações realizadas pela mesma, assim como as prisões efetuadas, os flagrantes e objetos que são apreendidos.É a mídia que não encontra limites e que cresce infinitamente a partir do lucro dado pela veiculação do espetáculo. Mostrando uma realidade mais caótica do que ela é para alcançar lucro, por objetivos privados por meio da banalização da violência, do crime, que explora a exaustão da morte, do sangue, do ridículo e o aberrante, havendo um apoio popular a essa espetacularização dos fatos, com edições de imagem que incrementam a cultura da violência e do medo.

\subsection{PERCEPÇÃO SUBJETIVA DE INSEGURANÇA E MEDO}

O jornalismo justiceiro lança diariamente diversas notícias de crimes, criando na população uma sensação de insegurança coletiva. Quando a notícia foi divulgada, a sociedade já está envolvida pelo medo, escolhe-se um delito com certa repercussão e, caso ele não exista, a mídia acaba por maquiar um crime mais simples, e assim inicia-se a espetacularização midiática do medo. Muito bem discorre sobre isso Jobin (2012):

A sensação de insegurança é pintada com cores tão exageradas, que a população amedrontada não quer saber de ouvir falar em estado democrático de direito, em direito penal garantista com princípios como presunção de inocência, contraditório, ampla defesa e juiz natural. Quer o castigo cruel e imediato de todo aquele sobre o qual recai um adminículo qualquer de suspeição. De repente é como se voltássemos 
aos tempos primevos da vingança privada e passássemos a adotar a lei do olho por olho, dente por dente.

Os meios de comunicação contribuem para a difusão do medo e da insegurança, expondo de forma exagerada uma sociedade violenta e desordenada. São programas que expõem imagens de violência como forma de chocar a população como se todos aqueles fatos violentos ocorressem continuamente em todos os cantos do país.

Mas aqui falamos de uma falsa realidade, construída por alguns profissionais que não possuem compromisso com a ética e a realidade dos fatos, como já discutido anteriormente. Pois sabem bem estas pessoas, que o crime, ao mesmo tempo em que causa terror, atrai a curiosidade da população, transmitindo a essa ou ela ideias de vingança, desejo de fazer justiça com as próprias mãos, maior ação punitiva do Estado, e jargões comuns no meio popular como: "bandido tem que mofar na cadeia", "a polícia prende, mas a justiça solta”, "o Brasil é o país da impunidade", etc.

A sensação de pânico e de terror consome o espectador sendo uma imagem virtual que não condiz com a realidade. O resultado disso é a construção de estereótipos do “criminoso", ponto que trataremos a seguir.

\subsection{FOMENTO DOS ESTEREÓTIPOS CRIMINOSOS}

Diante desta especularização da violência e da insegurança o espectador passa a acreditar veemente que a qualquer momento pode ser vítima de um delito demasiadamente exposto na mídia, ensejando a criação da ideia de "inimigo", despertando na sociedade os seus sentimentos mais preconceituosos, principalmente após uma cobertura que identifica os violadores da norma como aqueles "monstros perigosos e insensíveis".

O suspeito é estigmatizado. Há uma propagação de ideias incitando ao linchamento, de que "bandido deve sofrer", remontando aos ideais inquisitoriais de tempos passados. Pessoas apenas suspeitas em um inquérito policial já se encontram condenadas nos foros dos jornais, além de terem a sua vida, imagem, honra e privacidade destruídas.

Isso repercute no inconsciente do individuo, que muitas vezes ao visualizar pessoa em situação de rua ou de mendicância, por exemplo, já possui um senso comum, uma visão estereotipada daquela pessoa, e a define como sendo um possível ladrão, passando a julgá-la apenas pelo grupo socioeconômico do qual faz parte. Sendo essa estereotipada como "indivíduo suspeito", com "cara de bandido", em razão de características cumulativas, como: 
está mal vestido, sujo, reside em periferia, tatuado, pobre, de pele escura, sem instrução, dentre outras.

Isso significa que a maioria da população carcerária é constituída por negros e pobres, não porque estes cometem mais crimes, mas sim porque são mais vulneráveis ao controle penal, em virtude deles possuírem o estereótipo do criminoso construído socialmente, através da interação social.

Sendo os estereótipos mecanismos de seleção, explicando o porquê de a população carcerária ser tão uniforme: "O estereótipo alimenta-se das características gerais dos setores majoritários mais despossuídos e, embora a seleção seja preparada desde cedo na vida do sujeito, é ela mais ou menos arbitrária” (ZAFFARONI, 1991, p. 134).

Através desta realidade percebe-se que as pessoas que estão nos órgãos de controle penal agem de acordo com os estereótipos. Restando a mídia reproduzir estes discursos, repercutindo sempre no mesmo problema, gerando um círculo vicioso, como Budó (2011, online) aduz:

\footnotetext{
As notícias acabam realimentando os estereótipos e o senso comum sobre o crime e os criminosos, e posteriormente, ao construir novos relatos, se realimentarão, reproduzindo os estigmas. É a dialética que move a construção social da realidade, na qual os meios de comunicação desempenham um papel importantíssimo.
}

Zaffaroni (1991), de forma mais incisiva e energética, assevera que a mídia é uma fábrica de realidade, e que os meios de comunicação acabam assumindo funções como a fabricação dos estereótipos dos criminosos. Tudo isso leva à consideração de que o exercício de poder do sistema penal não seria possível sem a propaganda estabelecida pelos meios de comunicação de massa (ZAFFARONI, 1991, p. 127).

\subsection{A CONSTRUÇÃO DA VÍTIMA HERÓI}

Como demonstrado anteriormente, existe uma espécie de repulsa à pessoa do criminoso, que é diferenciado do "cidadão do bem". Há uma empatia da sociedade com a figura da vítima, as pessoas conhecem sua história e muitas vezes criam um laço, uma identificação ou imaginam que poderia ser alguém que lhe é próximo. Como afirma Luiz Flávio Gomes (2009, on-line), "sempre existiu uma natural empatia (da população) em relação a algumas vítimas de delito. O que agora mudou é que agora essa empatia é midiatizada, ou seja, potencializada e retroalimentada, porque ela passa a constituir um ‘produto midiático' (altamente rentável)”. 
Assim, é possível perceber a caracterização da vítima/herói, e o delinquente como vilão. Aquela tende colocar a culpa da violência e na incapacidade das autoridades estatais de reprimir e prevenir crimes. Dessa forma, a justiça quando deixada sob o comando do povo, fica tomada pela emoção, que fala mais alto que a razão, recaindo na questão já tratada da "banalização do crime", em que poucos se perguntam de onde vem o criminoso, se o mesmo teve ou não família, foi educado ou não, em que ambiente social foi criado etc. $O$ chamativo midiático está na manipulação da dor da vítima ou da sua família.Tal fato é enfatizado por Zaffaroni (2007, p.75) no seguinte trecho:

\footnotetext{
Com freqüência instrumentalizam-se vítimas ou seus parentes, aproveitando, na maioria dos casos, a necessidade de desviar culpas e elaborar o dolo, para que encabecem campanhas de lei e ordem, nas quais a vingança é o principal objetivo. As vítimas assim manipuladas passam a opinar como técnicos e como legisladores e convocam os personagens mais sinistros e obscuros do autoritarismo penal ao seu redor, diante dos quais os políticos amedrontados se rendem, num espetáculo vergonhoso para a democracia e a dignidade da representação popular.
}

A mídia constrói o inimigo e explora o fato criminoso visando apenas o lucro, mas como consequência, desperta na população o sentimento de vingança que vê na própria pele a dor das vítimas.

\section{ASPECTOS POSITIVOS DA MÍDIA JORNALÍSTICA}

É necessário salientar que a influência midiática, traz consequências graves, mas há também aspectos positivos, como o fato de mudanças em leis. A sociedade clama por leis mais severas, como exemplo, tem-se o assassinato da atriz Daniella Peres. A genitora da vítima, a autora Glória Perez, conseguiu com a repercussão gerada através da mídia, divulgar e colher mais de 1,3 milhões de assinaturas para inserir o crime de homicídio qualificado no rol de crimes hediondos. E assim foi feito, enviado ao Senado essas assinaturas, e criando, por meio de iniciativa popular a Lei ${ }^{\circ}$ 8.930/94.

É através do jornalismo comprometido, que é possível localizar criminosos e, assim ajudar no trabalho da polícia, em efetuar a prisão deles, em razão da grande divulgação. São crimes que por muitas vezes são evitados, através de campanhas de conscientização, da prevenção.

A mídia possui influência positiva quando se limita a exposição dos fatos de forma imparcial, realizando apenas o seu papel de informar sobre os fatos ocorridos. Facilitando o entendimento do público sobre os atos processuais, em razão de promotores, defensores, 
juízes, dos sujeitos processuais, utilizarem-se de linguagem técnica de difícil compreensão, permitindo apenas aos próprios operadores do direito compreenderem. Sendo a imprensa um importante transmissor da informação, devendo o fazer de forma clara ao leigo, ou seja, utilizando-se de linguagem mais simples. Sendo entendido este por Vieira (2003, p. 106) como "um dos pontos mais positivos e relevantes da publicidade processual proporcionada pela imprensa".

Isto porque a sociedade deve fiscalizar os atos do Poder Judiciário, mas para a realização deste é necessário que se entenda tais atos, para que se possa opinar, sobre algo que saiba.

Todavia, para que a imprensa possa cumprir essa função, é óbvio que precisa ter um razoável conhecimento jurídico, no que tange ao desenrolar do processo, referente aos termos utilizados, bem como sobre o que significa o ato que se noticia. Tal tarefa não é fácil, mas de forma alguma poderá ser dispensada, sob pena de se desconstituir a referida função (VIEIRA, 2003, p. 109).

Sendo assim, traduz o linguajar jurídico, dando publicidade aos atos processuais, democratizando a notícia e repercutindo positivamente, em outros pontos, como na diminuição da criminalidade, pois é ela quem acaba por esclarecer às normas penais a população.

\section{COLISÃo ENTRE A LibERDAde dE EXPRESSÃO E O DIREITO DE UM JULGAMENTO CRIMINAL JUSTO (INJUSTO)}

Até aqui procurou-se demonstrar a forma como a mídia lida com o fato criminal, como este processo pode comprometer o julgamento justo. Assim, é necessário ressaltar uma das conquistas do Estado Democrático, qual seja,: a liberdade de expressão, que é direito fundamental consagrado nos incisos, IV, V e IX do artigo $5^{\circ}$ da Constituição Federal de 1988, os quais determinam "é livre a manifestação do pensamento, sendo vedado o anonimato", "é assegurado o direito de resposta, proporcional ao agravo, além de indenização por dano material, moral ou à imagem" e ser livre é a "expressão de atividade intelectual, artística, cientifica, e de comunicação, independentemente de censura ou licença”.

Mais adiante no texto constitucional, encontramos outras disposições pertinentes à liberdade de expressão, em um capítulo dedicado à Comunicação Social, dos artigos 220 a 224 da CF/1988, ligados a atividade profissional da imprensa, dos quais tratam da proibição da censura; dos princípios de produção e programação de emissoras de rádio e televisão; das 
condições para a propriedade destes veículos; da concessão, permissão e autorização para o seu funcionamento.

A problemática insurge exatamente no fato de coberturas jornalísticas de feitos criminais de forma espetacularizada, porém uma suposta proibição destas informações, não seria compatível com a Constituição Federal de 1988. Deve-se identificar quando se está efetivamente diante de uma matéria, 'campanha de mídia' instaurada contra determinado acusado, que possa influenciar o resultado do julgamento.

São reportagens prejudiciais e impróprias aquelas que veiculam provas obtidas por meios ilícitos, tais como, gravação sem autorização; quebra do sigilo profissional advogadocliente; confissões obtidas de forma irregular, como as por meio de ameaça, tortura; conversas telefônicas interceptadas sem a prévia autorização da autoridade competente, etc.

Logo, o mero indício de contato do juiz ou testemunhas, com a prova obtida por meio ilícito, já é suficiente para a deficiência da realização de um julgamento criminal justo. Como Stephen Krause citado por Schreiber et al (2010, p. 348) afirma:

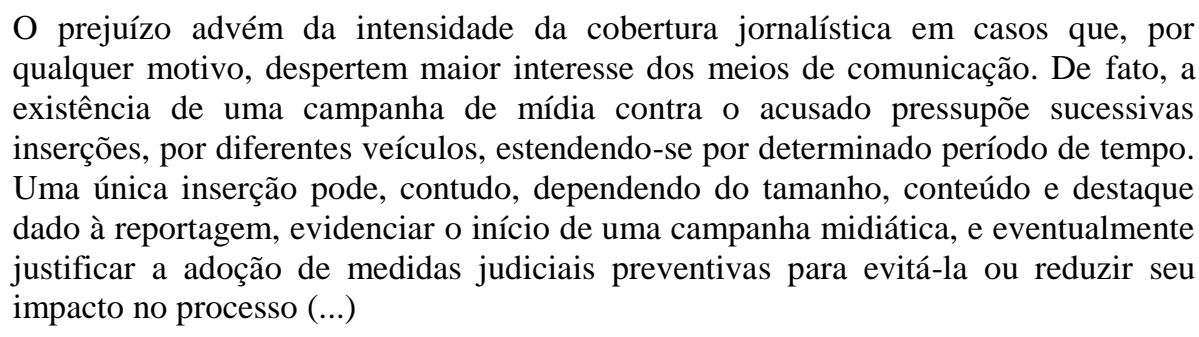

Ou seja, a depender da duração da matéria ou ainda a sua ênfase a determinado acusado, será prejudicial ao julgamento daquele. A colisão entre a liberdade de expressão e o direito ao julgamento criminal justo, parte desde a instauração do inquérito até o julgamento definitivo da causa.

Não se discute a proibição de reportagens no curso do processo, mas apenas campanhas de mídia que integradas sucessivamente influenciam indevidamente no resultado do julgamento.

Logo nesta colisão é necessário se fazer uso da ponderação buscando a harmonia no exercício dos direitos em questão, sempre a depender do caso concreto, e havendo a preservação do direito em si.

Em decisões do STF, confirma-se a tendência do Judiciário brasileiro em garantir a maior liberdade possível à imprensa, principalmente no que tange à crítica, desde que não recaia em práticas delituosas e a ofensa direta: 
EM DANOS MORAIS. ALEGADO EXCESSO NO DIREITO DE CRÍTICA JORNALÍSTICA. NÃO OCORRÊNCIA. VERACIDADE DE INFORMAÇÕES VEICULADAS. LIBERDADE DE CRÍTICA. AGRAVO A QUE SE NEGA PROVIMENTO. I - A crítica jornalística, ainda que elaborada em tom mordaz ou irônico, não transborda dos limites constitucionais da liberdade de imprensa. II - Agravo regimental a que se nega provimento. (RE 652330 AgR, Relator(a): Min. RICARDO LEWANDOWSKI, Segunda Turma, julgado em 25/06/2014, ACORDÃO ELETRONICO DJe - 159 DIVULG 18-08-2014 PUBLIC 19-08-2014)

\section{7 ÉTICA E A MÍDIA}

É necessário ainda levantar questões no que tange à ética na prática midiática, e estendê-las ao aspecto jurídico. A profissão do jornalista é regida por um código de ética, vigente desde 1987, e revisado em 2007. Trouxe uma importante contribuição:

Art. 11. O jornalista não pode divulgar informações:
I - visando o interesse pessoal ou buscando vantagem econômica;
II - de caráter mórbido, sensacionalista ou contrário aos valores humanos,
especialmente em cobertura de crimes e acidentes;
III - obtidas de maneira inadequada, por exemplo, com o uso de identidades falsas,
câmeras escondidas ou microfones ocultos, salvo em casos de incontestável
interesse público e quando esgotadas todas as outras possibilidades de apuração
(BRASIL, 2007)

Campo crescente é o do dito jornalismo investigativo. Na investigação, o repórter descobre documentos e provas desconhecidas do público. Sendo de grande importância para a coletividade, funcionários públicos são incitados a trabalhar, a não serem corruptos.

São matérias-denúncia, que crescem nos telejornais brasileiros. É a imprensa pressionando as instituições em nome do interesse público. Um repórter, que se utiliza de "táticas" similares às da polícia ao sair em busca de informações, consultas em documentos públicos, agindo como um verdadeiro "detetive". No entanto, a ética perde seu em reportagens veiculadas, por exemplo, no programa Fantástico, da TV Globo. Provas são obtidas infringindo o código de ética, imagens e confissões "obtidas de maneira inadequada, com o uso de identidades falsas, câmeras escondidas ou microfone oculto", como diz o código em seu artigo 11, inciso III.

São jornalistas que se valem de todos os instrumentos disponíveis para revelar informações através de câmeras escondidas e falsa identidade. Cometendo dois crimes, o primeiro de falsa identidade, ou seja, fazer passar por outra pessoa, conforme o Código Penal preceitua: 
Art. 307 - Atribuir-se ou atribuir a terceiro falsa identidade para obter vantagem, em proveito próprio ou alheio, ou para causar dano a outrem:

Pena - detenção, de três meses a um ano, ou multa, se o fato não constitui elemento de crime mais grave. (BRASIL, 1940)

E o segundo, contra os direitos individuais das pessoas, conforme artigo $5^{\circ}$, inciso $\mathrm{X}$ da Constituição Federal:

X - são invioláveis a intimidade, a vida privada, a honra e a imagem das pessoas, assegurado o direito a indenização pelo dano material ou moral decorrente de sua violação (BRASIL, 1988)

Sendo imprescindível ouvir a versão da outra parte, exercer o contraditório, esquecido nestas matérias. O jornalista pode investigar, mas sua função é informar. E quem julga, quem condena e quem absolve é o juiz. Porém, não é o que ocorre. há jornalistas que fazem de tudo: investigam, denunciam, julgam e condenam. É necessário "nortear" a ação do jornalista para que ele faça um bom jornalismo, não fique preso à pressa de divulgar o "furo" de reportagem. As questões éticas devem ser uma constante na vida daqueles, em razão da sua responsabilidade, já que a profissão é uma atividade de natureza social.

\section{CASOS CONCRETOS}

Durante a elaboração este trabalho, é possível perceber o contraponto existente em um jornalismo exercido em prol do lucro, da especularização, como também a importância significativa deste meio para publicidade dos atos processuais.

A formação da imagem do acusado como o vilão e a vitimização do ofendido apresentada pela mídia, o esclarecimento dos atos processuais, divulgação da realidade de forma comprometida, a localização de criminosos, a criação de leis, dentre outros demonstram o poder de influência midiática sobre o sistema judiciário. Analisaremos agora alguns acontecimentos de grande repercussão, que na prática, trouxeram à tona o grande poder da mídia, inicialmente de forma positiva, e por fim um caso de repercussão negativa. 


\subsection{O CASO ELIZA SAMÚDIO}

O caso refere-se ao desaparecimento da atriz pornográfica e modelo Eliza Samúdio, amante do ex-goleiro do Flamengo, Bruno. O caso foi escolhido pela mídia ${ }^{36}$ pois Eliza anunciou publicamente a gravidez do goleiro do Flamengo.

Em 2009, Eliza prestou queixa na polícia após afirmar que sofreu ameaças de Bruno devido à sua gravidez, explicitando que teria sido mantida em cárcere privado, por Russo e Macarrão, amigos de Bruno, e, posteriormente, condenados por envolvimento no crime, bem como, obrigada a tomar remédios abortivos e sofrido espancamento (TERRA, 2013) ${ }^{8}$.

Segundo informações, antes de desaparecer, Eliza teria contado à sua família que iria até a chácara do goleiro para que pudessem conversar. Depois disso, a vítima desapareceu e até hoje não foram encontrados restos mortais que indiquem a morte de Eliza, porém a sua morte presumida para a defesa, assim como foi confessada por algumas pessoas envolvidas no crime.

Em março de 2012, foi realizado o julgamento, condenando o ex-goleiro a 22 anos e três meses de reclusão. Além das condenações de outros envolvidos e comparsas de Bruno, os quais contaram em detalhes como foi realizada a captura de Eliza, sua morte e ocultação de seu corpo.

Percebe-se a influência da mídia no sistema judiciário pois o caso repercutiu de tal forma, que não se falava de outro assunto nos diversos meios de comunicação. Aos quais buscavam por versões, declarações dos investigadores, assim como dos diretamente envolvidos no crime, auxiliando as autoridades judiciárias na busca da verdade.

\subsection{O CASO ESCOLA BASE}

O fato teve início em 28 de março de 1994, com uma denúncia de abuso sexual contra crianças de quatro anos de idade, numa escola na zona sul de São Paulo, a Escola de Educação Infantil Base ${ }^{37}$. As acusações aceitas pelo delegado de polícia Edélcio Lemos e noticiado como furo de reportagem pela TV Globo.

\footnotetext{
${ }^{36}$ Eliza Samúdio: veja detalhes do crime. Terra. Disponível em: http://www.terra.com.br/noticias/infograficos/caso-bruno/. Acesso em: 08/11/2015

${ }^{37}$ Caso Escola Base completa 20 anos e acusados ainda buscam recomeço. Adital, notícias da América latina e caribe. Disponível em: http://site.adital.com.br/site/noticia.php?lang=PT\&cod=798.
} 
A partir daí a imprensa, a opinião pública e a maioria dos veículos de imprensa, acusaram, julgaram e condenaram Icushiro Shimada, Maria Aparecida Shimada, Mauricio Alvarenga e Paula Milhim Alvarenga.

O destaque dado pela imprensa passou a ser a cobrir a história em que os protagonistas eram crianças de apenas quatro anos de idade que eram drogadas e fotografadas nuas.

"Kombi era motel na escolinha do sexo", estampou o extinto jornal Notícias Populares, editado pelo Grupo Folha. "Perua escolar carregava crianças para a orgia", manchetou a também extinta Folha da Tarde. Porém na esfera jurídica, a história tomou outros rumos. O inquérito foi arquivado por falta de provas, todos os indícios foram apontados como inverídicos e infundados. No entanto, a escola já havia sido completamente depredada pela população revoltada ${ }^{12}$.

Posteriormente com o encerramento das investigações, a imprensa, através de imposição judicial, foi ordenada a divulgar o erro. Porém, a vida dos acusados nunca mais foi à mesma. Sendo o caso um exemplo de referência quanto à má apuração por parte da polícia e da imprensa.

\section{CONSIDERAÇÕES FINAIS}

Percebemos ao longo do trabalho, como também dos exemplos aqui narrados, que a mídia jornalística, em muitos casos, vai além do simples dever de informar. No entanto, devese observar que a mídia não manipula na mesma intensidade que imaginamos ou, ao menos, que se imagina.

Existe nas pessoas a capacidade de discernimento na ação midiática, de fazer a diferença entre o que é realidade e o mero espetáculo, fantasia. A mídia precisa ser refletida por todos, em razão do que a mesma nos apresenta, e de como esta contribui para a nossa formação e vice-versa. Ou seja, uma troca, que molda a mídia e a experiência das pessoas.

O que deve-se observar é o limite quanto ao jornalismo espetacular, o qual aponta culpados e os condena antes mesmo de serem submetidos ao poder judiciário, influenciando sobremaneira a opinião daqueles que não tem acesso às verdadeiras informações.

A mídia jornalística possui sua importância, mas necessita ser mais cuidadosa quanto às suas exposições, quanto à exploração desordenada de fatos delituosos, a qual cria verdadeiros espetáculos. Buscando-se assim um equilíbrio, um comprometimento com a realização de um jornalismo ético e distante do sensacionalismo e especularização da notícia, 
pois qualquer um poderá, por qualquer motivo, estar ali, ocupando o banco dos réus. Logo, é necessário que haja o comprometimento do escopo fundamental do Direito, qual seja: o alcance da justiça.

\section{REFERÊNCIAS}

ABRAMO, Perseu. Padrões de manipulação na grande imprensa. 1. ed. São Paulo: Fundação Perseu Abramo, 2003.

ALMEIDA, Débora de Souza; GOMES, Luiz Flávio. Populismo Penal Midiático: caso Mensalão, Mídia disruptiva e Direito Penal crítica. 1. ed. São Paulo: Saraiva, 2013.

BARBOSA, Marco Antonio. Poder na Sociedade da Informação. In O direito na Sociedade da Informação. Coord. Liliana Minardi Paesani. São Paulo: Atlas, 2007. p. 51.

BOURDIEI, Pierre. O Poder Simbólico. Tradução Fernando Tomaz. Rio de Janeiro: Bertrand Brasil, 2000. $3^{\text {a }}$ Ed.

BUDÓ, Marília Denardin. O espetáculo do crime no jornal: da construção social da criminalidade à relegitimação do sistema penal. Disponível em: <http://www.egov.ufsc.br/portal/sites/default/files/anexos/33470-43144-1-PB.pdf> Acesso em: 28 out. 2015.

BRASIL. Constituição Federal, 13. ed. São Paulo: RT, 2011.

Código de Ética Jornalística. 17. ed. São Paulo: RT, 2008.

Código Penal. 6. ed. São Paulo: RT, 2007.

BRITO Auriney Uchôa. Poder da Mídia: uma análise do direito penal na sociedade da informação. Disponível em: 
<http://www.publicadireito.com.br/conpedi/manaus/arquivos/Anais/sao_paulo/2517.pdf>. Acesso em: 25 ago. 2015.

CÍCERO, Natali Carolini de Oliveira. A influência da mídia sobre o juiz penal e a sociedade. Disponível em: <http://intertemas.unitoledo.br/revista/index. php/ETIC/article/viewFile/2367/1899>. Acesso em: 21 ago. 2015.

COSTA, Roger. O Poder Simbólico e a Mídia. Disponível em:

<http://www.regenciacoletiva.com/2013/02/o-poder-simbolico-e-midia.html>. Acesso em: 30 ago. 2015.

DEBORD, Guy. A sociedade do espetáculo. Rio de Janeiro: Contraponto, 1997.

DISCIONÁRIO HOUAISS. Violência. Disponível em: <http://houaiss.uol.com.br/>. Acesso em: 22 set. 2015.

DIAS, Jorge de Figueiredo; ANDRADE, Manuel da Costa. Criminologia: o homem delinqüente e a sociedade criminógena. Coimbra: Coimbra, 1997.

FERREIRA, Carla Danielle Lima Gomes. A influência da mídia no Processo Penal Brasileiro e a ruptura dos direitos fundamentais sobre o acusado. Jurisway, 2014. Disponível em: <http://www.jurisway.org.br/v2/dhall.asp?id_dh=13766> Acesso em: 22 nov. 2015 .

GOMES, Luiz Flávio. Mídia, direito penal e vingança popular. Disponível em: <http://jus.com.br/artigos/12956/midia-direito-penal-e-vinganca-popular> Acesso em: 05 nov. 2015 .

G1 - O portal de notícias da globo. Caso Elisa Samudio. Disponível em: <http://g1.globo.com/minas-gerais/julgamento-do-caso-eliza-samudio/>. Acesso em: 30 out. 2015. 
JOBIN, Jorge André Irion. Vingança Privada. Disponível em:

<http://www.midiaindependente.org/pt/red/2012/09/512478.shtml> Acesso em: 01 nov. 2015.

JÚNIOR, Gilson. Estereótipos de pessoa suspeita de ser criminosa. Disponível em:

<http://www.recantodasletras.com.br/textosjuridicos/4193692> Acesso em: 15 out. 2015.

NJAINE, Kathie. Violência na mídia, excessos e avanços. Disponível em:

<http://www.unicef.org/brazil/pt/Cap_04.pdf> Acesso em: 02 nov. 2015.

PADILHA NETO, José Cavalcanti. Liberdade de expressão e direitos fundamentais: a imprensa nos tribunais. Via Jus, Porto Alegre, 2006. Disponível em:

<http://www.viajus.com.br/viajus. php?pagina=artigos\&id=489\&idAreaSel=16\&seeArt=yes > Acesso em: 25 set. 2015.

SILVERSTONE, Roger. Por que estudar a mídia? 2. ed. São Paulo: Loyola, 2005.

SHECAIRA, Sérgio Salomão. A mídia e o direito penal. Boletim IBCCRIM. São Paulo, n.45, p. 16, ago. 1996.

SCHREIBER, Simone. A publicidade opressiva dos julgamentos criminais. Revista brasileira de ciências criminais, São Paulo, n. 86, set./out. 2010. Quadrimestral.

VIEIRA, Ana Lúcia Menezes. Processo Penal e Mídia. São Paulo: Editora Revista dos Tribunais, 2003.

ZAFFARONI, Eugenio Raúl. O inimigo no direito penal. 2 ed. Rio de Janeiro: Revan, 2007.p. 75

Em busca das penas perdidas: A perda de legitimidade do sistema penal. Rio de Janeiro: Revan, 1991. 


\title{
THE GAP BETWEEN THE MEDIA REALITY AND REALITY OF PROCEDURE
} AND ITS IMPLICATIONS FOR CRIMINAL TRIAL FAIR.

\begin{abstract}
Address shall be aspects of the reality of the facts brought about by the media at the criminal trial, which plays an important role in society, as the oversight, given the information, as well as, their interference to building an unreal reality by specularization the facts. And how this influence society and the judiciary, particularly in the matter of a fair criminal trial. From a deductive method, it aims to analyze the influence of the construction of reality, through an approach with the use of specific cases, showing the existing dissonance between the reality of the facts and the media reality. This research has a descriptive purpose, through the use of bibliographic object.
\end{abstract}

Keywords: Media. Manipulation. Judicial system. 